\title{
Meal feeding and leucine utilization in pregnant rats
}

\author{
BY P. J. M. WEIJS, V. V. A. M. SCHREURS AND H. N. A. GROOTEN \\ Department of Human and Animal Physiology, Wageningen Agricultural University, Haarweg 10, \\ 6709 PJ Wageningen, The Netherlands
}

(Received 12 October 1993-Revised 31 May 1994 - Accepted 14 June 1994)

\begin{abstract}
During pregnancy a higher amino acid requirement may be expected, but the increase in food intake does not match the increased growth rate during pregnancy. It is hypothesized that amino acid utilization can be increased during both fasting and feeding in order to account for the increased requirement. Therefore mature female rats ( 20 weeks old) were investigated before and at day 18 of pregnancy. Rats were fed on a high-protein (HP) diet (210 $\mathrm{g}$ casein/ $\mathrm{kg}$ diet) for 3 weeks and fasted overnight. Rats were then subjected to an $8 \mathrm{~h}$ constant infusion of $\mathrm{L}-\left[1-{ }^{14} \mathrm{C}\right]$ leucine with continuous measurement of expired ${ }^{14} \mathrm{CO}_{2}$ (as a percentage of the infused dose). After $3 \mathrm{~h}$ infusion a $5 \mathrm{~g} \mathrm{HP}$ or low-protein (LP; $75 \mathrm{~g}$ casein/ $\mathrm{kg}$ diet) meal was offered for $\mathbf{3 0} \mathrm{min}$. Pregnant rats had a significantly lower percentage leucine oxidation in the fasted state (12.5 (SE 0.7) v. 15.9 (SE 1.1)\%;P<0.05), which suggests improved reutilization of lencine. Meal ingestion resulted in a fast increase in ${ }^{14} \mathrm{CO}_{2}$ expiration. After the $\mathrm{LP}$ meal the level of ${ }^{14} \mathrm{CO}_{2}$ expiration decreased again after the acute response (0-1.5 h), but this was not the case after the HP meal. After the HP meal (average 1.5-5 h), no difference was observed between pregnant and nonpregnant status (36.8 (SE 1.6) v. 35.0 (SE 2.5)\%). After the LP meal (average 1.5-5 h), however, the percentage leucine oxidation tended to be lower in pregnant rats but this difference did not reach statistical significance (19.7 (SE 1.1) v. 25.8 (SE 2.8)\%). In conclusion, pregnancy improved leucine utilization in the fasted state, and tended to improve it after marginal protein feeding.
\end{abstract}

Amino acid: Feed intake: Leucine: Pregnancy: Rat

Naismith (1969) found that increased $\mathbf{N}$ retention in the pregnant rat was primarily deposited in the maternal carcass $(67 \%)$ in the first 2 weeks of pregnancy and in products of conception (84\%) in the last week of pregnancy. Naismith \& Morgan (1976) then proposed to call these periods the anabolic and catabolic phases of pregnancy in the rat. Mayel-Afshar \& Grimble (1983) found muscle protein to be increased in the anabolic phase, even on a protein-deficient diet. Ling et al. (1987) found muscle protein to decrease between days 17 and 20 of pregnancy in well-fed rats, but Mayel-Afshar \& Grimble (1983) only found a decrease in protein-deficient rats. At the same time (final week of pregnancy) fetal and placental protein is increased substantially (Mayel-Afshar \& Grimble, 1982, 1983; Ling et al. 1987, 1989). The normal increase in liver protein during pregnancy does not occur when dietary protein is deficient (Mayel-Afshar \& Grimble, 1983). Although feed intake increases during pregnancy up to several days before delivery (Mayal-Afshar \& Grimble, 1983; Moore \& Brasel, 1984), the above suggests a complex repartitioning of protein between pools instead of direct deposition of dietary protein. It has been suggested that amino acid oxidation might be decreased during pregnancy, as in protein deficiency (Naismith \& Fears, 1972). Mayel-Afshar et al. (1981) found the percentage oxidation of tyrosine to be decreased mainly in the catabolic phase, both in well-fed and proteindeficient rats.

In the present study we investigated the changes during pregnancy in leucine utilization in the fasted state and after feeding either a high- or a low-protein meal. 
Table 1. Experimental design

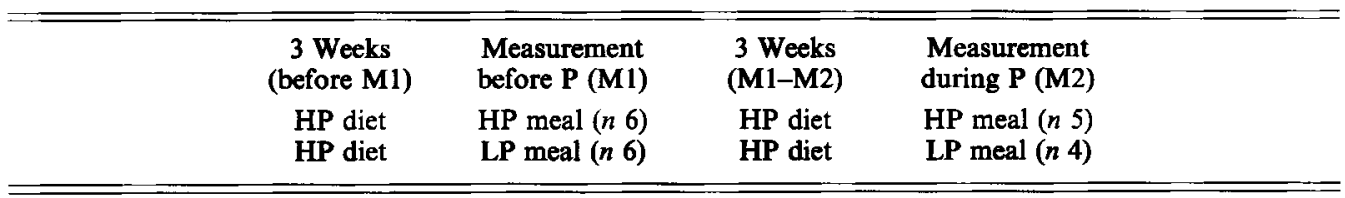

$\mathrm{M}$, measurement $\left({ }^{14} \mathrm{CO}_{2}\right.$ breath test); $\mathrm{P}$, pregnancy; HP, high protein; LP, low protein.

\section{MATERIALS AND METHODS}

\section{Animals and diets}

Female Wistar-WU rats $(n 15 ; 20$ weeks old; Centre for Small Laboratory Animals, Wageningen Agricultural University, Wageningen, The Netherlands) were housed in individual cages with bedding material (Woody-Clean type 8/15, Broekman Institute Ltd., Someren, The Netherlands). Room temperature was $22-23^{\circ}$. Rats were conditioned on a high-protein (HP) diet ( $210 \mathrm{~g}$ casein $/ \mathrm{kg} \mathrm{diet)} \mathrm{for} 3$ weeks before pregnancy (see Table 1 ). One week before the first breath test all rats were provided with a silicon heart catheter through the right jugular vein, for continuous infusion of tracer (Steffens, 1969). Rats were offered feed between 09.00 and 17.00 hours for 4 weeks before the first experiment (light period: 06.00-20.00 hours). Oestrus status was checked daily by vaginal lavages, in order to indicate phase of oestrus cycle. Rats were subjected to a ${ }^{14} \mathrm{CO}_{2}$ breath test both $2 \mathrm{~d}$ before pregnancy (day 2 or 3 of the dioestrous phase; $n 12$ ) and on day 18 of pregnancy $(n 9)$. Diets were made isoenergetic through exchange of protein with carbohydrate (Schreurs $e t$ al. 1992).

\section{${ }^{14} \mathrm{CO}_{2}$ breath test}

All rats were subjected twice to an $8 \mathrm{~h}$ infusion with $\mathrm{L}-\left[1-{ }^{14} \mathrm{C}\right]$ leucine $(4 \cdot 6 \mathrm{kBq} / \mathrm{h}$, $2.0 \mathrm{GBq} / \mathrm{mmol}$, Amersham, Den Bosch, The Netherlands; total volume $2 \mathrm{ml}$ ). Rats were either offered a HP meal (non-pregnant, $n 6$; pregnant, $n$ 5) or a LP meal (non-pregnant, $n 6$; pregnant, $n 4$ ); if possible the same rats were used on both occasions. Three hours after the start of infusion the $5 \mathrm{~g}$ test meal was offered for $30 \mathrm{~min}$. The ${ }^{14} \mathrm{CO}_{2}$ expiration was measured continuously (at intervals of $15 \mathrm{~min}$ ) and expressed as a percentage of the infused dose, as described previously (Weijs et al. 1993).

The effect of pregnancy was analysed by ANOVA and differences between means were analysed by Student's $t$ test for independent samples, using the SPSS software package (SPSS Inc., 1988).

\section{RESULTS}

Fig. 1 shows that feed intake increased slightly but significantly during pregnancy, but there was a slight reduction in feed intake by day 18 of pregnancy. During the same stages of pregnancy daily weight gain (DWG) increased significantly, with a 3- to 6-fold increase for day 18 compared with the earlier stages of pregnancy. Fig. 2 shows that ${ }^{14} \mathrm{CO}_{2}$ expiration increased 2- to 3-fold upon ingestion of the LP and HP meals respectively. After the acute response to meal ingestion $(0-1.5 \mathrm{~h})$, the ${ }^{14} \mathrm{CO}_{2}$ expiration decreased following the $\mathrm{LP}$ meal to a constant level but remained higher than the fasted level. In the fasted state the ${ }^{14} \mathrm{CO}_{2}$ expiration was significantly lower for pregnant rats (12.5 (SE 0.7) v. 15.9 (SE 1.1)\%; $P<0.05$ ). After feeding the LP meal the average ${ }^{14} \mathrm{CO}_{2}$ expiration was lower, but this did not reach statistical significance $(19.7$ (SE 1-1) v. 25.8 (SE 2.8)\%). After feeding the HP meal there was no difference between the non-pregnant and the pregnant status (36.8 (SE 1.6) $v$. 


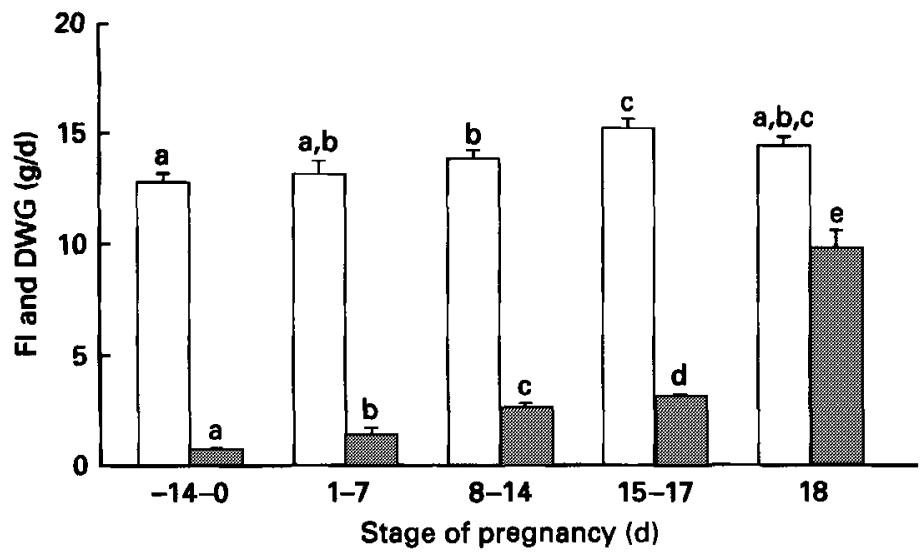

Fig. 1. Changes in food intake (FI; $\square$ ) and daily weight gain (DWG; 图) with pregnancy in rats. Values are means with their standard errors indicated by vertical bars. Bars not sharing a common character were significantly different $(P<0.05)$. For details, see p. 254.

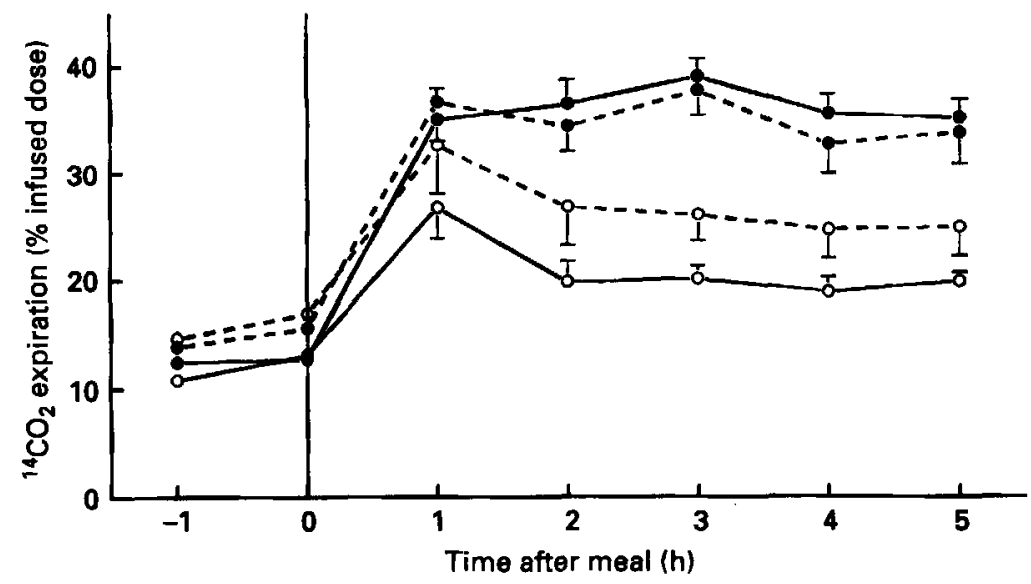

Fig. 2. Acute changes in ${ }^{14} \mathrm{CO}_{2}$ expiration by rats after a high-protein meal (O), or a low-protein meal $(O)$, before pregnancy (--) or during pregnancy $(-)$. Values are means with their standard errors indicated by vertical bars. For details, see p. 254.

35.0 (SE 2.5) \%). Analysis of variance showed a significant effect of pregnancy $(P<0.001)$ in the fasted state, but not after feeding. Before feeding there was no significant difference between the groups that received different meals. From 2 to $5 \mathrm{~h}$ after the meal the effect of protein content of the meal was highly significant $(P<0.001)$. The different effect of the protein level between pregnant and non-pregnant rats could only be supported statistically by a borderline significant interaction term between protein meal and pregnancy $(P<0 \cdot 1)$.

\section{DISCUSSION}

Although pregnancy is an interesting physiological phenomenon in itself, the primary objective of the present study was to check whether growth during pregnancy had comparable effects on leucine utilization as growth during development. In an earlier study with male rats, growth significantly improved leucine utilization in the fasted state as well 
as after feeding (Weijs et al. 1993). The method used in the present study is identical to that used in the previous study, which is discussed below.

During pregnancy the mature female rat seems to gain muscle protein in the first 2 weeks (Poo et al. 1940; Naismith, 1969; Mayel-Afshar \& Grimble, 1983), and placental and fetal protein in the last week of pregnancy (Mayel-Afshar \& Grimble, 1982, 1983; Ling et al. 1987, 1989). In the last week of pregnancy the placental and fetal tissues seem to gain protein at the expense of muscle tissue protein (Naismith, 1969; Ling et al. 1987), although it is suggested that this is only necessary on protein-deficient diets (Mayel-Afshar \& Grimble, 1983). These alterations suggest the need for improved utilization, especially when protein intake is marginal.

Recently the 'diurnal cycling' of protein was proposed and described as one of the main mechanisms for regulation of body protein mass (Millward \& Rivers, 1988; Millward et al. 1991 ; Price $e t$ al. 1994). It involves protein loss during fasting and protein gain after feeding in both growing and mature animals and humans. Transient protein gain after feeding is likely to occur in gut and liver, which can subsequently supply amino acids to muscle tissue (Simon, 1989). Maternal muscle protein gain after feeding with subsequent amino acid release in the fasted state has been suggested to be essential for fetal development (Ling et al. 1987, 1989). When amino acid release in the fasted state was reduced by continuous feeding, fetal growth was retarded (Ling et al. 1989). Therefore, (1) an intermittent feeding regimen for rats was adopted, in order to enable 'diurnal cycling' of protein, and (2) efficiency of leucine utilization (see next paragraph) was measured during both fasting and at two levels of (acute) protein intake.

\section{On the method}

In the present study it was intended to investigate the qualitative effect of pregnancy on the efficiency of leucine utilization during fasting and feeding. For this study the simplest approach was adopted, which had been shown previously to be valuable (Weijs et al. 1993). The fate of leucine was traced with $\left[{ }^{14} \mathrm{C}\right]$ leucine, and the oxidized part was measured continuously. Therefore the percentage leucine oxidation was measured, which provides a relative measure of leucine utilization, indicating the partitioning of available leucine to either leucine oxidation or protein synthesis. Thus this measure provides an insight into the efficiency of leucine utilization in the short term $(<1 \mathrm{~h})$. At present we accept some possible disadvantages of this method.

\section{Adaptation to pregnancy}

Although food intake does increase with pregnancy, it does not match the increase in DWG during pregnancy, especially on day 18 of pregnancy when feed intake drops and DWG is 3-6 times DWG during earlier stages of pregnancy. Gain of body water probably accounts for a large part of this increase in DWG. However, based on the literature (Naismith, 1969; Mayel-Afshar \& Grimble, 1983; Ling et al. 1987), alterations in amino acid utilization at day 18 of pregnancy may be expected and could account for part of the discrepancy between a slight decrease in feed intake and an enormous increase in DWG. In the fasted state pregnancy reduced the percentage of available leucine oxidized (Fig. 2), and this indicates that leucine reutilization is improved. Protein breakdown in maternal tissues supplies amino acids to the metabolic pool of free amino acids. This pool of amino acids is available for both protein synthesis in maternal tissues and amino acid oxidation. Amino acids cannot be stored and, therefore, any supply of amino acids above the uptake by protein synthesis has to be catabolized. In the case of pregnancy several options for adaptation are available, including changes in protein turnover, diurnal cycling and amino acid oxidation. It is clear that amino acids can be used for protein synthesis in both 
maternal and fetal tissues and that reutilization of leucine can be improved. On the other hand, mobilization of muscle protein (Naismith, 1969; Ling et al. 1987) should only occur to the extent necessary and therefore also improve utilization.

It remains to be shown that normal transient protein gain after feeding fully accounts for the fetal amino acid needs in the fasted state. When normal transient protein gain on a highprotein diet is high enough for this purpose, there is no need to improve leucine utilization after a high-protein meal. The present results seem to support this hypothesis, since leucine utilization after a high-protein meal was not improved for pregnant rats. However, it is also possible that the high-protein meal itself prohibits a reduction in leucine oxidation because of the large leucine influx from the high-protein meal. After a low-protein meal leucine utilization did seem to be improved in the pregnant rat, although the statistical significance of the effect was low $(0.1>P>0.05)$ and more studies will be required to confirm the responses. This indicates that when less dietary protein is available, the efficiency of utilization is immediately increased in pregnancy. This seems to be in line with the suggestion of Mayel-Afshar \& Grimble (1983) that muscle protein mobilization is only necessary when rats are fed on protein-deficient diets. The fact that the response to a lowprotein meal is so fast might be related to a mechanism that anticipates muscle protein mobilization. Therefore the adaptive mechanism seems to be available and is expressed acutely on ingestion of feed. In this way the pregnant animal tries to gain as much protein as possible. This is essentially the same as we previously observed with growing rats in comparison with mature rats (Weijs et al. 1993), although in growing rats leucine utilization was even improved after the high-protein meal. However this observation underlines how fast the response to acute protein supply is, especially when it is necessary for growth or pregnancy.

The present study shows a possible adaptation in amino acid utilization during pregnancy. More research is necessary to substantiate this adaptation and the mechanisms involved.

\section{REFERENCES}

Ling, P. R., Bistrian, B. R., Blackburn, G. L. \& Istfan, N. (1987). Effect of fetal growth on maternal protein metabolism in postabsorptive rat. American Journal of Physiology 252, E380-E390.

Ling, P. R., Bistrian, B. R., Blackburn, G. L. \& Istfan, N. (1989). Effect of continuous feeding on maternal protein metabolism and fetal growth in the rat. American Journal of Physiology 256, E852-E862.

Mayel-Afshar, S. \& Grimble, R. F. (1982). Tyrosine oxidation and protein turnover in maternal tissues and the fetus during pregnancy in rats. Biochimica et Biophysica Acta 716, 201-207.

Mayel-Afshar, S. \& Grimble, R. F. (1983). Changes in protein turnover during gestation in the foetuses, placentas, liver, muscle and whole body of rats given a low-protein diet. Biochimica et Biophysica Acta 756, $182-190$.

Mayel-Afshar, S., Grimble, R. F. \& Taylor, T. G. (1981). Tyrosine oxidation during pregnancy in normal and protein-deficient rats. Proceedings of the Nutrition Society 40, 36A.

Millward, D. J., Price, G. M., Pacy, P. J. H., Quevedo, R. M. \& Halliday, D. (1991). The nutritional sensitivity of the diurnal cycling of body protein enables protein deposition to be measured in subjects at nitrogen equilibrium. Clinical Nutrition 10, 239-244.

Millward, D. J. \& Rivers, J. P. W. (1988). The nutritional role of indispensable amino acids and the metabolic basis for their requirements. European Journal of Clinical Nutrition 42, 367-393.

Moore, B. J. \& Brasel, J. A. (1984). One cycle of reproduction consisting of pregnancy, lactation or no lactation, and recovery: effects on carcass composition in ad libitum-fed and food-restricted rats. Journal of Nutrition 114, 1548-1559.

Naismith, D. J. (1969). The foetus as a parasite. Proceedings of the Nutrition Society 28, $25-31$.

Naismith, D. J. \& Fears, R. B. (1972). Adaptations in the metabolism of protein during pregnancy in the rat. Proceedings of the Nutrition Society 31, 8A.

Naismith, D. J. \& Morgan, B. L. G. (1976). The biphasic nature of protein metabolism during pregnancy in the rat. British Journal of Nutrition 36, 563-566.

Poo, L. J., Lew, W., Lee, D. D. \& Addis, T. (1940). Protein anabolism in the organs and tissues of pregnant rats at different levels of protein consumption. Journal of Nutrition 19, 505-515.

Price, G. M., Halliday, D., Pacy, P. J., Quevedo, M. R. \& Millward, D. J. (1994). Nitrogen homeostasis in man: influence of protein intake on the amplitude of diurnal cycling of body nitrogen. Clinical Science 86, 91-102. 
Schreurs, V. V. A. M., Boekholt, H. A., Koopmanschap, R. E. \& Weijs, P. J. M. (1992). The metabolic utilization of amino acids: potentials of ${ }^{14} \mathrm{CO}_{2}$ breath test measurements. British Journal of Nutrition 67, $207-214$.

Simon, O. (1989). Metabolism of proteins and amino acids. In Protein Metabolism in Farm Animals. Evaluation, Digestion, Absorption, and Metabolism, pp. 273-366 [H.-D. Bock, B. O. Eggum, A. G. Low, O. Simon and T. Zebrowska, editors]. Oxford: Oxford Science Publications.

SPSS Inc. (1988). SPSS $/ \mathrm{PC}^{+}$Base Manual. Chicago, IL: SPSS Inc.

Steffens, A. B. (1969). A method for frequent sampling of blood and continuous infusion of fluids in the rat without disturbing the animal. Physiology and Behavior 4, 833-836.

Weijs, P. J. M., Schreurs, V. V. A. M., Koopmanschap, R. E., Grooten, H. N. A., Schoonman, A. T. \& Boekholt, H. A. (1993). Effects of acute and chronic level of protein supply on metabolic leucine utilization in growing and mature rats. British Journal of Nutrition 70, 117-125. 